\title{
Pengembangan Kawasan Wisata Hutan Mangrove Di Desa Nira Nusa Kecamatan Maurole Kabupaten Ende (Dengan Pendekatan Tema Ekowisata)
}

\author{
Guaredini Karlos Paso Pande ${ }^{1}$, *Dian Fitriawati Mochdar ${ }^{2}$, Fabiola T.A. Kerong ${ }^{3}$ \\ ${ }^{1,2.3}$ Program Studi Arsitektur, Fakultas Teknik, Universitas Flores, Ende \\ *) Correspondence e-mail: dianflomochdar@gmail.com
}

\begin{abstract}
ABSTRAK
Desa Nira Nusa Kecamatan Maurole Kabupaten Ende merupakan desa yang terletak di wilayah pesisir pantai laut Flores. Desa ini memiliki potensi ekowisata yang besar terutama ekosistem mangrove. Desa Nira Nusa memiliki banyak potensi sumberdaya wisata namun belum diteliti lebih lanjut dari aspek-aspek yang mendukung daerah ini untuk dikembangkan menjadi objek wisata mangrove, sehingga data dan informasinya masih bersifat umum. Untuk pengembangan wisata suatu daerah diperlukan kajian mendalam dari berbagai aspek. Maka perlu dilakukan penelitian yang bertujuan untuk mengetahui potensi dan daya tarik wisata mangrove yang ada di Desa Nira Nusa serta menghitung nilai keindahan dari potensi tersebut sehingga dapat dikembangkan menjadi kawasan wisata yang mendukung kelestarian alam serta meningkatkan kesejahteraan masyarakat stempat. Metode pengumpulan data dilakukan dengan pengamatan langsung di lapangan dan wawancara secara langsung dengan responden untuk memberikan penilaian terhadap keindahan potensi wisata. Hasil penelitian menunjukan bahwa potensi dan daya tarik objek wisata mangrove di Desa Nira Nusa adalah ekosistem mangrove, view ke arah pantai laut Flores, dan budaya serta potensi kearifan lokal. Kegiatan yang dapat dilakukan adalah berwisata, fotografi, memancing, pengamatan burung (bird watching), dan menikmati sunset. Potensi dan daya tarik wisata mangrove Desa Nira Nusa berdasarkan ruang lingkup site yang berada di area pesisir pantai laut Flores.
\end{abstract}

Kata kunci : Mangrove, Potensi wisata, Ekowisata, Berbasis masyarakat.

\section{PENDAHULUAN}

Hutan mangrove sebagai suatu ekosistem mempunyai potensi keindahan alam dan lingkungan berupa komponen penyusun eksoistem yang terdiri dari vegetasi, biota atau organisme asosiasi, satwa liar, dan lingkungan sekitarnya. Fungsi lingkungan hutan mangrove antara lain sebagai habitat, daerah pemijahan, penyedia unsur hara, dan lain sebagainya. Hutan mangrove juga merupakan areal tempat penelitian, pendidikan, dan ekowisata (Massaut 1999 dan FAO 1994). Perkiraan luas mangrove di Indonesiamencapai $\pm 2,5$ juta hektar dan menurut Ditrektorat Bina Program Inventarisasi dan Tata Guna Hutan (1996) luas mangrove mencapai \pm 3.5 juta hektar.

Menurut Wiharyanto (2007) sebagai suatu ekosistem khas perairan pesisir, hutan mangrove memiliki nilai ekologis dan ekonomis. Hutan ini menyediakan bahan dasar untuk keperluan rumah tangga dan industri, seperti kayu bakar, arang, kertas dan rayon, yang dalam konteks ekonomi mengandung nilai komersial tinggi. Hutan mangrove memiliki fungsi-fungsi ekologis yang penting, antara lain sebagai penyedia nutrien, tempat pemijahan (spawning grounds), daerah asuhan (nursery grounds) dan tempat mencari makan (feeding grounds) bagi biota laut tertentu. Ekosistem ini, pada kawasan tertentu bersifat open acces, sehingga meningkatnya eksploitasi oleh manusia akan menurunkan kualitas dan kuantitasnya. Menurut Kustanti dan Yulia (2005), manfaat lain dari hutan mangrove adalah jasa ekowisata.

Memperhatikan pentingnya kawasan wisata sebagai sarana untuk mendukung konservasi lingkungan yang sesuai dengan kondisi dimana wisatawan saat ini cukup peka terhadap masalah lingkungan, maka konsep-konsep kawasan wisata dikembangkan sehingga timbul inovasi-inovasi baru dalam kepariwisataan.

Potensi mangrove juga terdapat di Kabupaten Ende, hal ini dapat dilihat pada Kecamatan Maurole dimana sepanjang pesisir pantainya memilki beberapa potensi hutan mangrove khususnya Desa Nira Nusa yang 
memiliki sebuah kawasan hutan mangrove yang masih bersifat alami dan belum terjamah. Selain memiliki potensi kawasan hutan mangrove yang dapat dijadikan kawasan wisata, Desa Nira Nusa memiliki beberapa potensi dan karakteristik antara lain potensi yang sangat menonjol yaitu; potensi Pertanian dan Perkebunan.

Menerutu data profil Desa Nira Nusa, memiliki letak geografis yangberada di bagian Barat dari pusat ibukota Kecamatan Maurole, dengan ketinggian antara $0 \mathrm{~m} \mathrm{~s}$ s/d $350 \mathrm{~m}$ dari permukaan laut (dpl), kondisi alam yang terdiri dari dataran dan perbukitan dengan curah hujan rata-rata per tahun antara 7-9 bulan hujan. Suhu harian rata-rata $25^{\circ} \mathrm{C} \mathrm{s} / \mathrm{d} 30^{\circ} \mathrm{C}$. Selain itu masyarakat Desa Nira Nusa juga memiliki 2karakteristik yaitu:

1. Pembangunan yang dilaksanakan berbasiskan pada potensi sumber daya, adat dan budaya lokal masyarakat setempat.

2. Secara Budaya Lokal Masyarakat Desa Nira Nusa memiliki 5 (lima) jenis karakteristik yaitu:

- Tedo tembu wesa wela (Pertanian)

- Gaga boo kewi ae (Perkebunan, kehutanan)

- Peni nge wesi nuwa (Peternakan)

- Teka laku daga geti (Perdagangan, Industri, Koperasi, UMKM)

- Wenggo nua nena ola (Membuat Kampung menjadi Indah / Pelestarian Lingkungan Hidup)

Melihat beberapa potensi dan karakteristik Desa Nira Nusa yang diambil penulis pada data profil Desa Nira Nusa yang diberikan langsung dari Sekertaris Desa, bahwa menurut pengertian dan pemahaman penulis kawasan hutan mangrove di Desa Nira Nusa sangat cocok untuk dijadikan pengembangan kawasan wisata berbasis masyarakat dengan penerapan tema Ekowisata. Lokasinya sangat ideal dan memiliki potensi karena posisinya tepat melindungi kawasan area pesisir pantai, terletak dekat dengan pemukiman warga, pemandangannya yang lasung berhadapan dengan sebuah pulau yaitu Palue dan yang terakhir letaknya sangat strategis berada dekat dengan jalan raya.

Pentingnya lokasi hutan mangrove di Desa Nira Nusa ini selain sebagai tempat perlidungan habitat laut, hutan mangrove ini juga perlu adanya sebuah tempat pengembangan destinasi wisata di Kabupaten Ende, melihat dari karakteristik warga masyarakat dan potensi Desa Nira Nusa menguatkan penulis untuk melanjut tulisan ini juga dilokasi hutan mangrove belum ada sebuah kawasan wisata berbasis masyarakat bagi Desa Nira Nusa itu sendiri.

Pada lokasi hutan mangrove di Desa Nira Nusa perlu adanya sebuah jalur pedestrian yang dimana memudahkan para wisatawan dapat menikmati keindahan alam hutan mangrove dengan menyediakan beberapa fasilitas utama seperti cafe, ruang pertunjukan, dan penginapan, hal tersebut di perlakukan karena kawasan tersebut belum adanya penerapan konsep perencanaan dan peracangan kawasan wisata hutan mangrove di Desa Nira Nusa itu sendiri.

Aksesbilitas menuju hutan mangrove yang kurang memadai dimana area sirkulasi menuju kawasan tersebut terletak diantara permukiman warga yang biasa digunakan keluar masuknya kendaraan (mobil dan sepeda Motor) serta pejalan kaki warga sekitar, karena aksesjalan masuk kedalam lokasi kawasan Hutan Mangrove tersebut menggunakan satu jalan stapak yang dapat berakibat kepadatan pengguna akses jalan tersebut.

Tujuannya adalah menyediakan kawasan wisata yang berbasis masyarakat di Desa Nira Nusa bersifat melidungi dengan tidak merusak keadaan alam sekitarnya serta mengetahui potensi dan kendala aspek biofisik, ekonomi dan sosial budaya bagi pengembangan wisata hutan mangrove di Desa Nira Nusa serta menentukan konsep perencanaan dengan tema arsitektur terpilih.

Dengan adanya pengembangan kawasan wisata Hutan Mangrove di Desa Nira Nusa ini dapat menujang kehidupan masyarakat pada sektor ekonomi dimana pada area luar lokasi kawasan hutan mangrove tersebut akan menyediakan beberapa sarana berupa stan - stan penjualan serta pada area didalam lokasi hutan mangrove menyediakan fasilitas seperti tempat kantor pengelola, penginapan dan cafe yang akan dibangun di lokasi kawasan hutan mangrove Desa Nira Nusa. 
Dalam penulisan ini penulis merencanakan membangun kawasan wisata hutan mangrove dengan penerapan tema ekowisata, tema ekowisata yang dimaksudkan didsini ialah merupakan salah satukegiatan pariwisata yang berwawasan lingkungan dengan mengutamakan aspek konservasi alam, aspek pemberdayaan sosial budaya ekonomi masyarakat lokal.

\section{Pengertian Pariwisata}

Menurut etimologi kata pariwisatadiidentikkan dengan kata travel dalam bahasa Inggris yang diartikan sebagai perjalanan yang dilakukan berkali-kali dari satu tempat ke tempat lain. Atas dasar itu pula dengan melihat situasi dan kondisi saat ini pariwisata dapat diartikan sebagai suatu perjalanan terencana yang dilakukan secara individu atau kelompok dari satu tempat ke tempat lain dengan tujuan untuk mendapatkan kepuasan dan kesenangan (Sinaga, 2010:12).

\section{Pengertian Wisata}

Wisata dalam bahasa Inggris disebut tour yang secara etimologi berasal dari katatorah (ibrani) yang berarti belajar, tornus (bahasa latin) yang berarti alat untuk membuat lingkaran, dandalam bahasa Perancis kuno disebut tour yang berartimengelilingi sirkuit. Pada umumnya orang memberi padanan kata wisata dengan rekreasi, wisata adalah sebuah perjalanan, namun tidak semua perjalanan dapat dikatakan wisata (Suyitno,2001).Menurut Fandeli wisata adalah perjalanan atau sebagai darikegiatan tersebut dilakukan secara sukarela serta bersifat sementara untuk menikmati objek dan daya tarik wisata.

Jenis - jenis wisata berdasarkan tempatnya :

1. Wisata Alam

Wisata Alam adalah suatu perjalanan yang memanfaatkan potensi sumber daya alam dan lingkungannya sebagai objek tujuan wisata, dimana objek wisata itu bisa menyuguhkan panorama keindahan alami dan ke ajaiban alam, yang bisa memberikan kesejukan, membuat kita merasa nyaman sehingga menghilangkan stress dan lain sebagainya. Contoh wisata alam adalah Pantai, Gunung, Hutan, Danau, kawah, air terjun dll.

2. Wisata Maritim atau Bahari

Wisata Martim atau Bahari adalah kegiatan wisata yang selalu dikaitkan dengan air seperti: olah raga di air, lebih-lebih di danau, pantai, teluk, atau laut seperti memancing, berlayar, menyelam sambil melakukan pemotretan, kompetisi berselancar, balapan mendayung, melihat-lihat taman laut dengan pemandangan indah di bawah permukaan air serta berbagai rekreasi perairan yang banyak dilakukan didaerah-daerah atau negara-negara maritim, di Laut Karibia, Hawaii, Tahiti, Fiji dan sebagainya.

3. Wisata Cagar Alam (Taman Konservasi)

Wisata Cagar Alam atau Taman Konservasi ini adalah wisata hayati untuk melihat pohon atau tanaman dan hewan2 dalam habitat tertentu, dan ini biasanya ada tour guide dari pemerintah setempat. Contoh: cagar alam, taman lindung, hutan daerah pegunungan dan sebagainya yang kelestariannya dilindungi oleh undang-undang.

\section{Pengertian Ekowisata}

Ekowisata adalah perjalanan wisata ke suatu lingkungan baik alam yang alami ataupun buatan serta budaya yang ada yang bersifat informatif dan partisipatif yang bertujuan untuk menjamin kelestarian alam dan sosial-budaya.Ekowisata menitikberatkan pada tiga hal utama yaitu, keberlangsungan alam atau ekologi, memberi manfaat ekonomi, dan secara psikologis dapat diterima dalam kehidupan social masyarakat (Hakim, 2004).

\section{METODE}

Metode penelitian yang digunakan yaitu kombinasi antara metode kuantitatif dan Kualitatif. Metode kuantitatif, metode penelitian yang digunakan dalam perhitungan secara akurat untuk menentukan 
kapasitas ruang dan pelaku kegiatan. Metode kualitatif, metode penelitian yang tidak terukur secara matematis yang diterapkan dalam konsep perancangan dan disesuai dengan tema arsitektur ekoklogi

\section{Metode Pengumpulan Data}

Metode yang digunakan untuk mepperoleh data sebagai berikut : Observasi yaitu pengamatan secara lansung pada lokasi peracangan dan berkaitan dengan lokaasi dan kondisi site dari lokasi yang telah di rencanakan. Melakukan observasi secara lasung dilokasi site yang berada di Desa Nira Nusa Kecamatan Maurole.Dokumentasi yaitu pengambilan foto bertujuan untuk mendapatkan gambaran datadata tentang kondisi existing misalnya tentang keadaan site, landuse, dan lain-lain. Wawancarayaitu tanya jawab dengan warga yang berada dekat sekitar obyek paeracangan atau instansi Desa Nira Nusa yang berhubungan dengan obyek perancangan.

\section{Metode analisis data}

Metode analisa data dapat dilakukan yaitu Analisa Kualitatif dan Analisa Kuantitatif.

\section{Metode perancangan.}

Metode peracangan yang dipakai dalam peracangan pengembangan kawasan wisata huta mangrove di Desa Nira Nusa. Mengunakan literatur dan juga pengumpulan data dari survey lapangan.

\section{Kompilasi Data}

Memilih data - data yang akan di ambil dari studi literatur dan survey lapangan untuk di evaluasi. Data yang terkumpul kemudian di analisa dengan mengunakan metode analisa kuantitatif maupun dengan mengunakan metode analisa kualitatif yang dikaitkan dengan tema peracangan.

\section{Konsep Peracangan}

Konsep peracanaan dan peracangan berdasarkan data yang telah di analisa sehingga dalam peracangan pengembangan kawasan wisata hutan mangrove di Desa Nira Nusa penulis dapat menerapkan konsep peracangan seseuai tema arsitektur ekowisata dengan memperhitungkan standar aksesibilitas di lokasi tapak tersebut.

\section{HASIL DAN PEMBAHASAN}

Site berada di kabupaten Ende, Kecamatan Maurole, Desa Nira Nusa tepatnya berada disekitar pesisir pantai laut Flores. Keadaan kondisi lahan pada Site ini terdapat dua area yaitu area darat dan area kawasan hutan mangrove. Letak site tidak jauh dari permukiman warga Desa Nira Nusa dan kantor Desa Nira Nusa . Site juga berada pada jalur utilitas seperti berada dekat dengan jalur mobilisasi (jalan), air bersih dan jalur jaringan listrik.

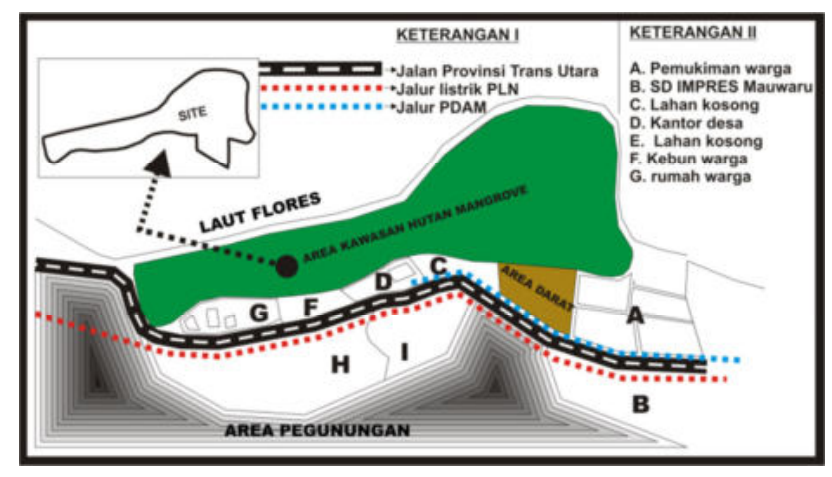

Gambar : Peta Site

\section{Karakteristik Tapak Site} Batas dengan lingkungan 

A. Sebelah Utara
: Laut Flores
B. Sebelah Selatan
: Kantor desa dan rumah warga
C. Sebelah Timur
: Jalan provinsi Lintas Flores
D. Sebelah Barat
: Laut Flores

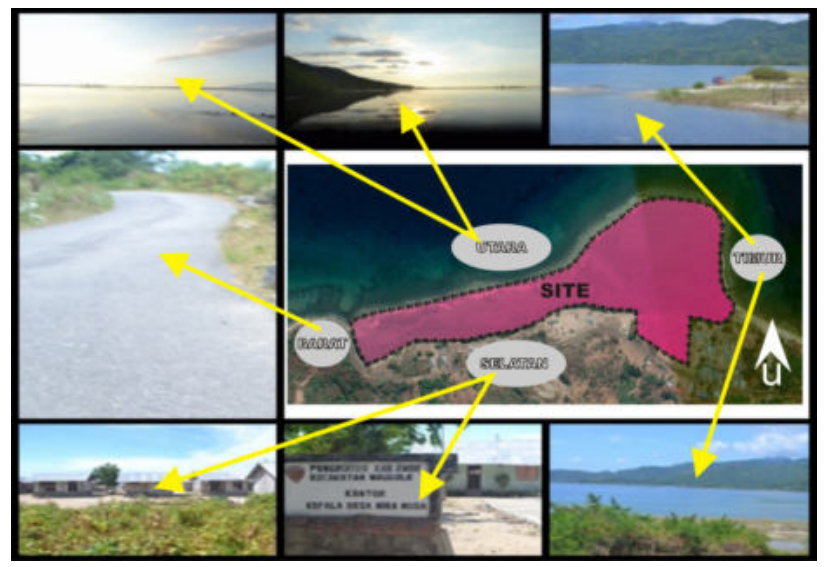

Gambar: Batas Site dengan lingkungan

\section{Ukuran Tapak}

Lokasi site merupakan kawasan hutan mangrove dengan dengan luas $20.276 \mathrm{~m}^{2}$. Pencapain ke lokasi mudah dicapai karena site berada cukup dekat dengan jalan raya dan pemukiman warga pemukiman warga. Ukuran site pada tapak yaitu :
a. Luas site
$: 20.276 \mathrm{~m}^{2}$
b. Panjang site
: barat $42 \mathrm{~m}$, timur $120 \mathrm{~m}$
c. Lebar site : utara 314, selatan $307 \mathrm{~m}$

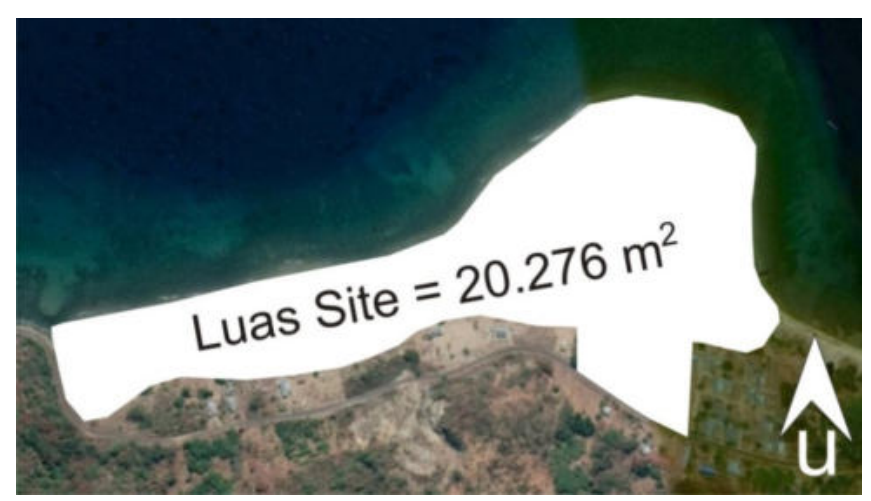

Gambar 4.6: Luas site

\section{Konsep Dasar}

Konsep dasar merupakan konsep inti perancangan yang didapatkan dari tema ekowisata untuk konsep perancangan Pengembangan Wisata Hutan Mangrove Desa Nira Nusa Kecamatan Maurole Kabupaten Ende.

\section{Tujuan Konsep Dasar}

Menjadikan obyek kawasan hutan mangrove Desa Nira Nusa sebagai sebuah obyek wisata yang dapat memberikan kontribusi secara nyata dalam bidang ekonomi khususnya terhadap masyarakat sekitar Desa 
Nira Nusa.

\section{Fungsi Konsep Dasar}

Fungsi dari konsep dasar ekowisata antara lain :

A. Sebagai sebuah tempat wisata yang mampu mengakomodir kebutuhan pariwisata bagi wisatawan yang berkunjung ke Kabupaten Ende khususnya di Desa Nira Nusa

B. Sebagai tempat yang menyediakan fasilitas stan penjualan atau lapak bagi masyarakat sekitar sesuia dengan potensi krakteristik Desa Nira Nusa sehingga keberlangsungan ekonomi masyarakat sekitar dapat tersalurkan agar dapat meningkatakan perekonomian masyarakat sekitar.

C. Mengoptimalkan obyek kawasan hutan mangrove Desa Nira Nusa menjadi tempat pariwisata yang mempunyai keindahan karakteristikfisik bersifat ramah lingkunga, ramah budaya dan adat setempat sebagai sebuah tujuan berwisata.

\section{Konsep Tapak}

Konsep tapak merupakan penetuaan tata letak masa bangunan pada Pengembangan Wisata Hutan Mangrove Desa Nira Nusa Kecamatan Maurole Kabupaten Ende berdasarkan analisis fungsi primer, sekunder dan penunjang. Potensi yang ada pada obyek kawasan site di bagi menjadi dua areayaitu,area daratan sebagai zona penerima sedangkan area dalam hutan mangrove dibagi lagi menjadi 4 zona yaitu penginapan, cafe, dermaga dan panggung pertunjukan.

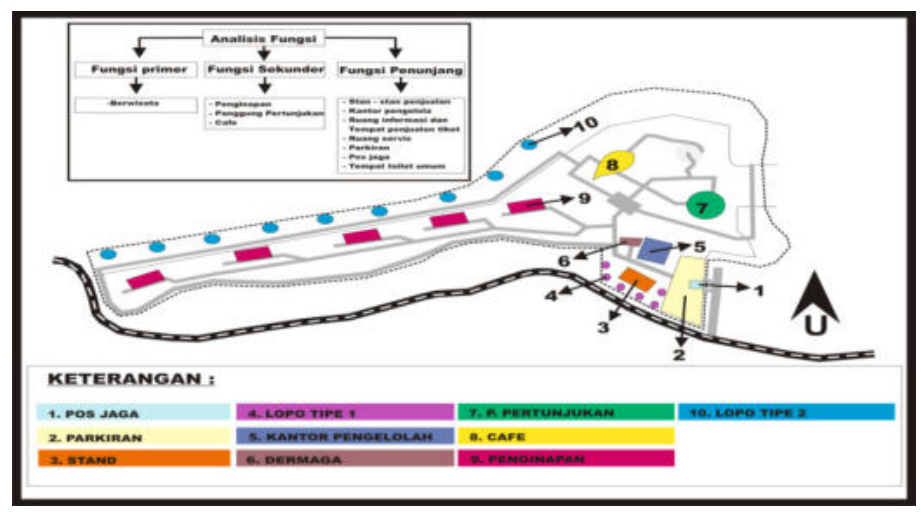

\section{Konsep Pezoningan}

Gambar : konsep Tapak

Ada beberapa kriteria dalam penentuan peletakan zoningyang ideal yaitu berdasarkan fungsi serta alur kegiattan aktifitas wisata, bentuk site, topografi, dan aksesibilitas. Konsep penzoningan ini diterapakn berdasarkan ukuran dan kondisi lahan pada tapak berdasarkan area lingkup site yang memiliki kondisi lahan dua area yaitu area kawasan hutan mangrove dan area darat.

Dalam konsep penzoningan ini, arae darat merupakan area dengan kapsitas ukuran paling kecil sehingga pada area ini di hanya terdapat zona penerima sedangkan pada kawasan hutan mangrove memiliki luasan area sangat besar dengan pembagiannya menjadi menjadi empat zona diantarannnya yaitu, zona penginpan, zona dermaga zona cafe dan zona pangung pertunjukan. 


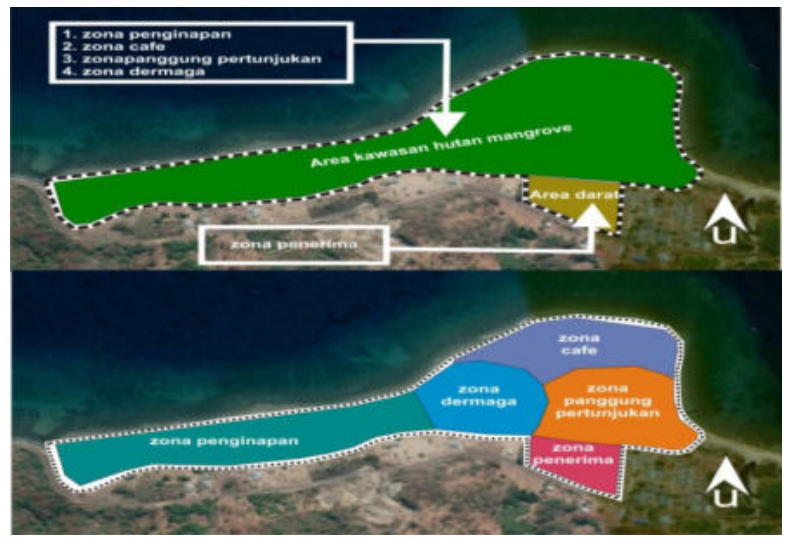

\section{Konsep Klimatologi}

\section{Gambar penzoningan}

Secara garis besar menjabarkan konsep klimatologi yaitu, berasal dari analisa matahari dan analisa angin dengan mengambil dari kesimpulan alternatif kedua analisa tersebut. Pada konsep klimatologi ini menerapakan satu jenis penerapan yang di terapakan pada Konsep matahari dan konsep angin.

1. Konsep matahari

Penerapan pada konsep matahari mengunakan solar cell yang di tempatkan pada zona penginapan, zona cafe, zona panggung pertunjukan dan zona penerima, pada atap bangunan di tiap - tiap zon

2. Konsep angin

Menerapakan pengolahan fasad bangunan dengan membuat membukaan - bukaan pada masa bangunan yakini bangunan pada zona penginapan, zona cafe dan zona penerima.

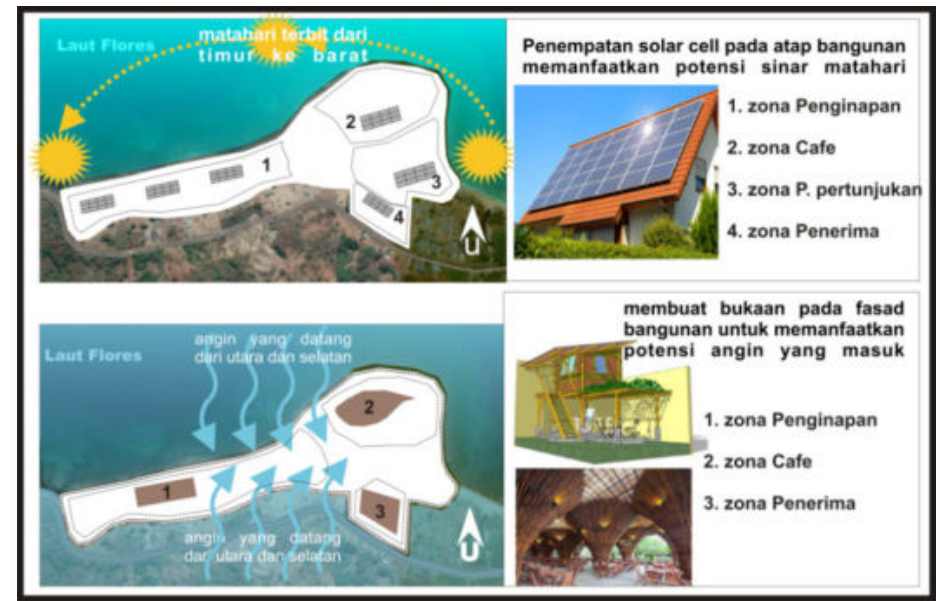

Gambar Konsep iklim

\section{Konsep view}

Memiliki potensi view yaitu, pada arah utar dan timur yang mana mengarah pada laut flores dan memiliki potensi yang sangat bagus sehingga dalam dalam konsep ini memilih alternatif 1 segai konsep desainnya nanti. 


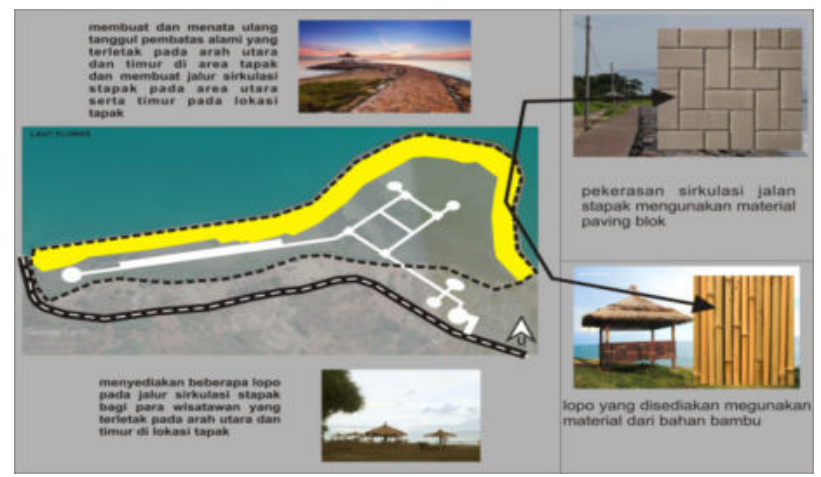

Gambar konsep view

\section{Konsep Struktur}

\section{Sub struktur}

Menerapkan sistim pondasi menerus dan pondasi umpak di area zona penerima yaitu, pada bangunan kantor pengelola dan stan penjualan, sedangkan pada araea hutan mangrovemenerapkan sistim pondasi tiang panca mengunakan material kayu ulin yaitu, pada zona penginapan, zona cafe, zona panggung pertunjukan dan zona dermaga.

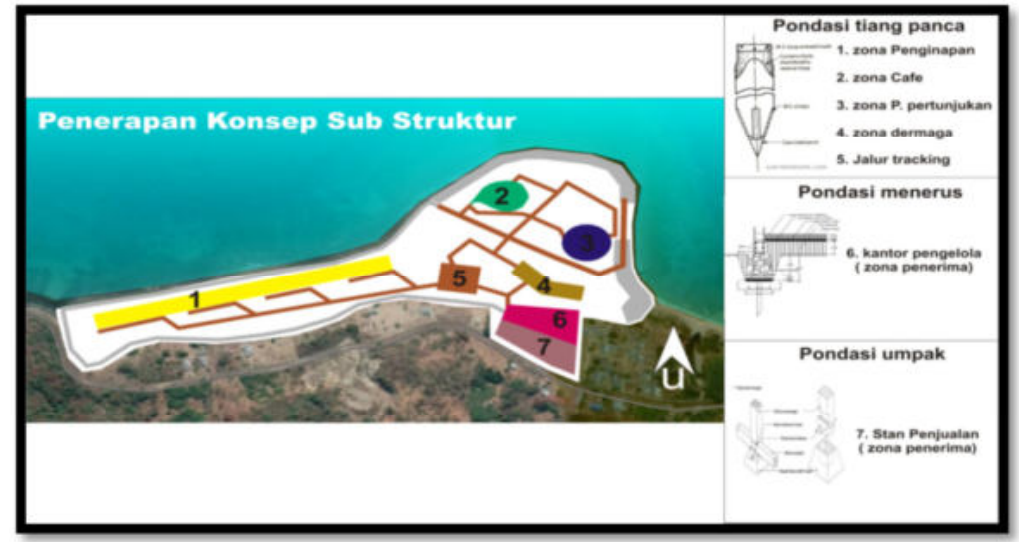

Gambar konsep Sub Struktur

\section{Super struktur}

Struktur rangka tengah menggunakan bahan dari bambu pada zona - zona tertentu.

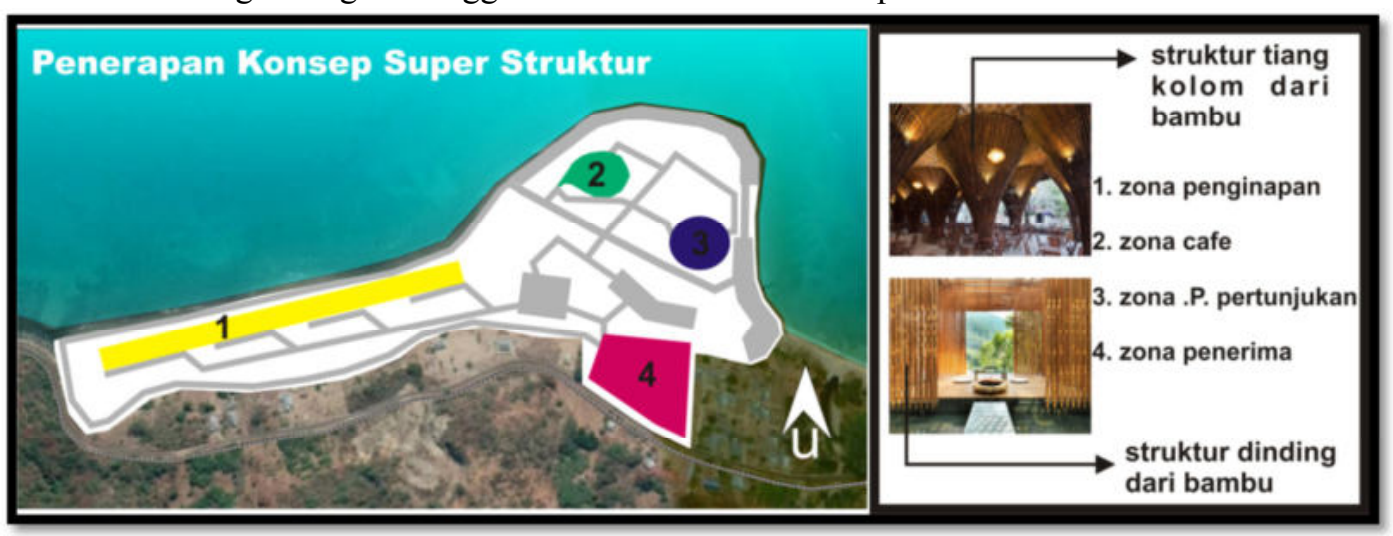

Gambar konsep Super Struktur 


\section{Upper Structure}

Bentuk struktur atas menerapkan gabungan bentuk setengah melingkar dan bentuk atap standar dengan pengunaan penutup atap mengunakan material bambu dan alang - alang.

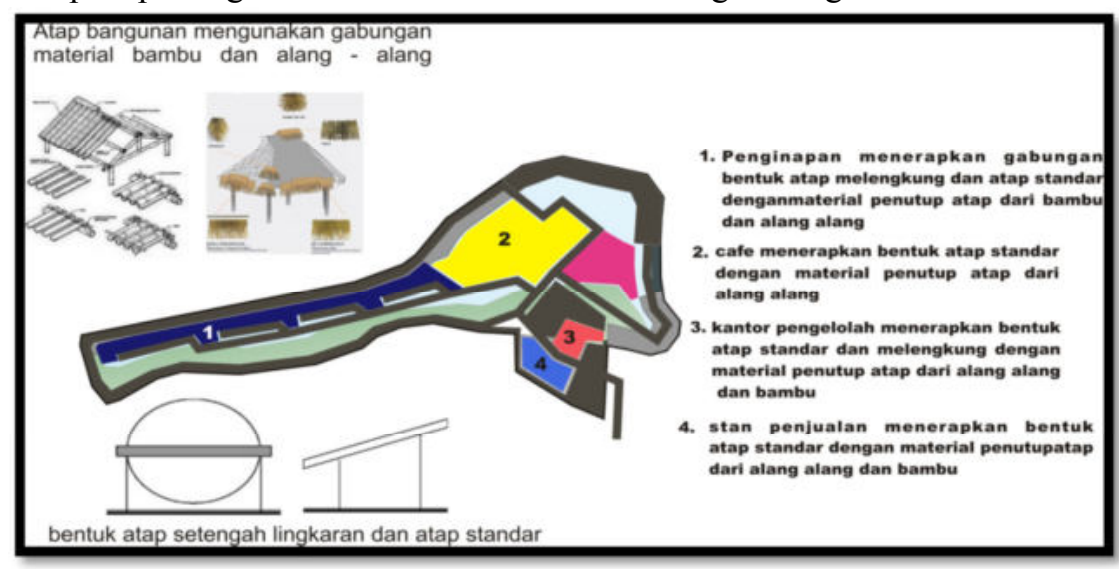

Gambar konsep Upper Structure

\section{Konsep Utilitas}

Pada Pengembangan Kawasan Wisata Hutan Mangrove Desa Nira Nusa Kecamatan Maurole Kabupaten Ende ini yang tidak boleh diabaikan adalah konsep perencanaan dan perancangan sistem utilitas. Konsep utilitas ini terdiri dari tiga konsep perancangan yang di ambil dari analisis dan alternatif utilitas yaitu antara lain, analisis alternatif sistem plumbing, analisis alternatif sistem sampah dan analisis alternatif sistem jaringan listrik.

\section{Konsep Sistem Plumbing}

Konsep sitem plumbing dibagi dalam 3 bagian yaitu :

1. Konsep air bersih

Sumber air bersih yaitu, memakai sumber dari PDAM dan air sumur tanah sebagai alternatifnya. Konsep yang di terapkan ini mengunakan toren air sebagai penganti bak penampung dan sistim perpiaan yang di distribusikan ke kawasan wisata mengunakan pipa HDPE ( pipa roll ).

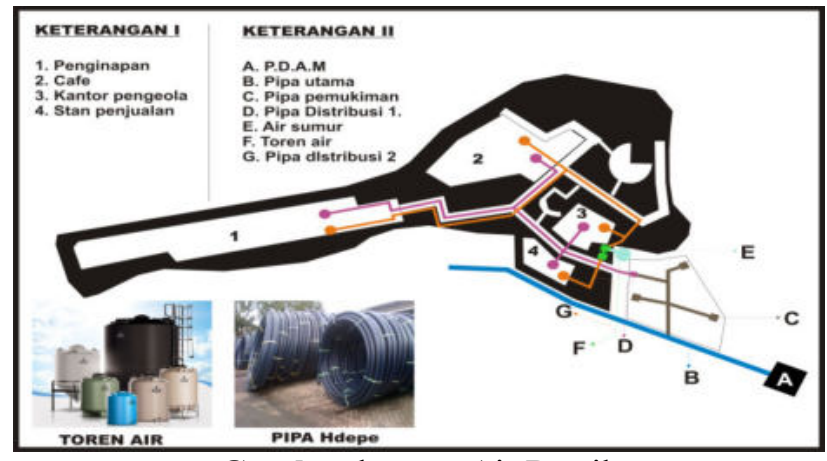

2. Konsep air kotor

Gambar konsep Air Bersih

Konsep air kotor padat mengunakan sepiteng ramah lingkungan sedangkan air kotor cair atau limbah dari peginapan, cafe, kantor pengelola dan stan penjualan mengunakan IPAL. Pada bangunan 
penginapan membutuhkan 6 sepiteng dari 18 masa penginapan dibagai 3 masa persatu sepiteng, cafe membutuhkan 2 sepiteng, kantor pengelola 1 sepiteng, stan penjualan 1 sepiteng sedangkan untuk pembuangan limbah mengunakan IPAL.

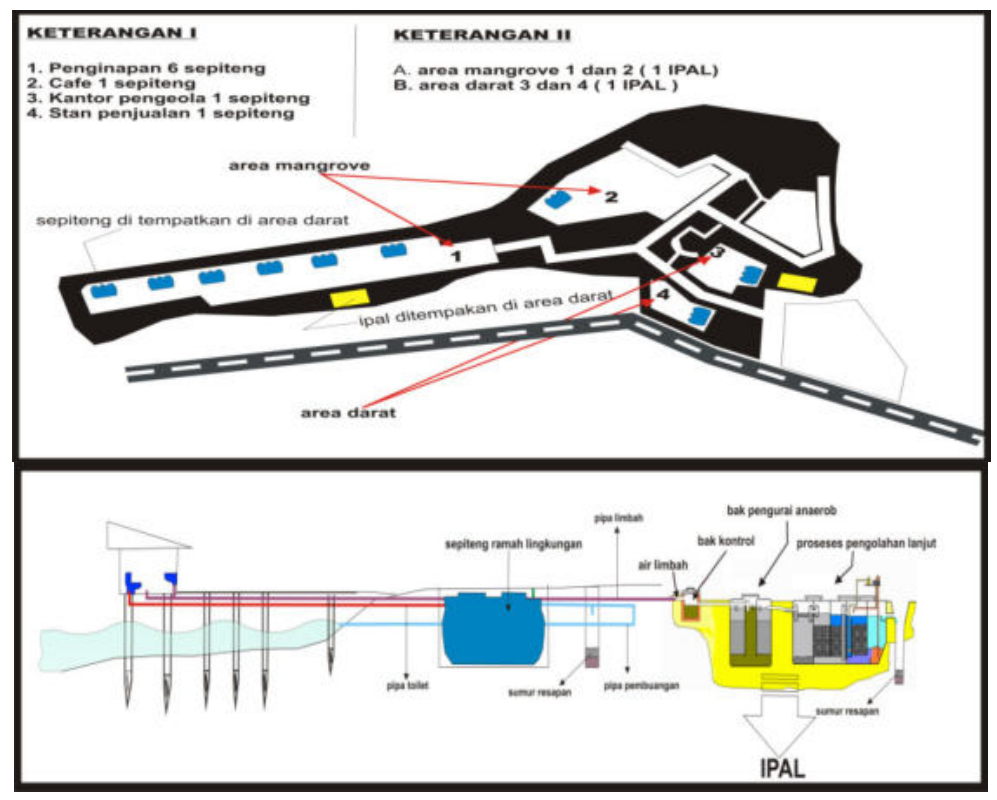

3. Konsep air hujan

\section{Gambar konsep Air Kotor}

Konsep air hujan yang terapkan cuma pada zona penerima saja dengan membuat selokan atau got pembuangan air hujan menuju kawasan hutan mangrove

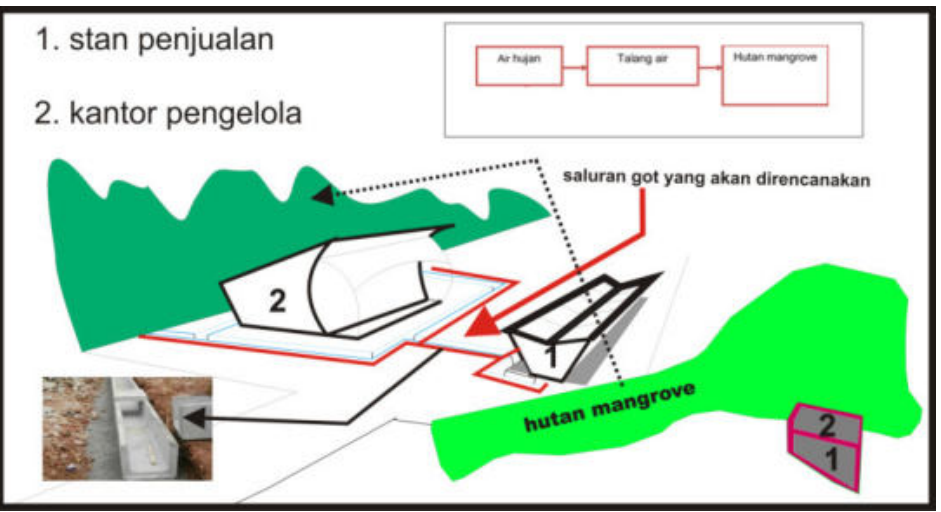

\section{Konsep Sistem Sampah}

Gambar konsep Air hujan

Tapak belum memilki tempat pembuangan sampah yang layak jadi dalam proeses pengembangan kawasan wisata hutan mangrove di Desa Nira Nusa Kabupaten Ende ini perlu ada sebuah konsep peracangan tempat pembuangan sampah yang layak. 


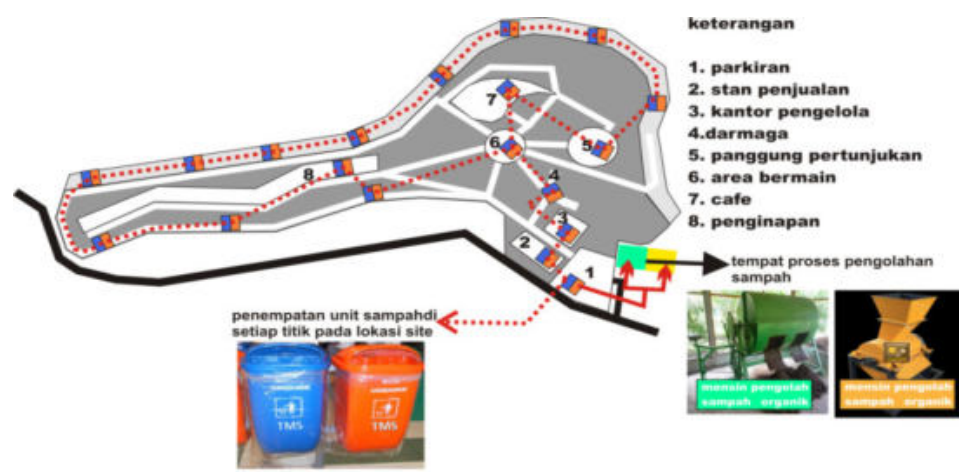

Gambar 6.19 konsep sistem sampah

\section{Konsep Sistem Jaringan Listrik}

Konsep jaringan listrik utama menggunakan aliran listrik dari PLN sedangkan konsep jaringan listrik alternatif mengunakan solar cell yang dikembangkan pada Pengembangan Kawasan Wisata Hutan Mangrove Desa Nira Nusa Kecamatan Maurole Kabupaten Ende ini dengan memanfaatkan sumber potensi alam yaitu matahari.
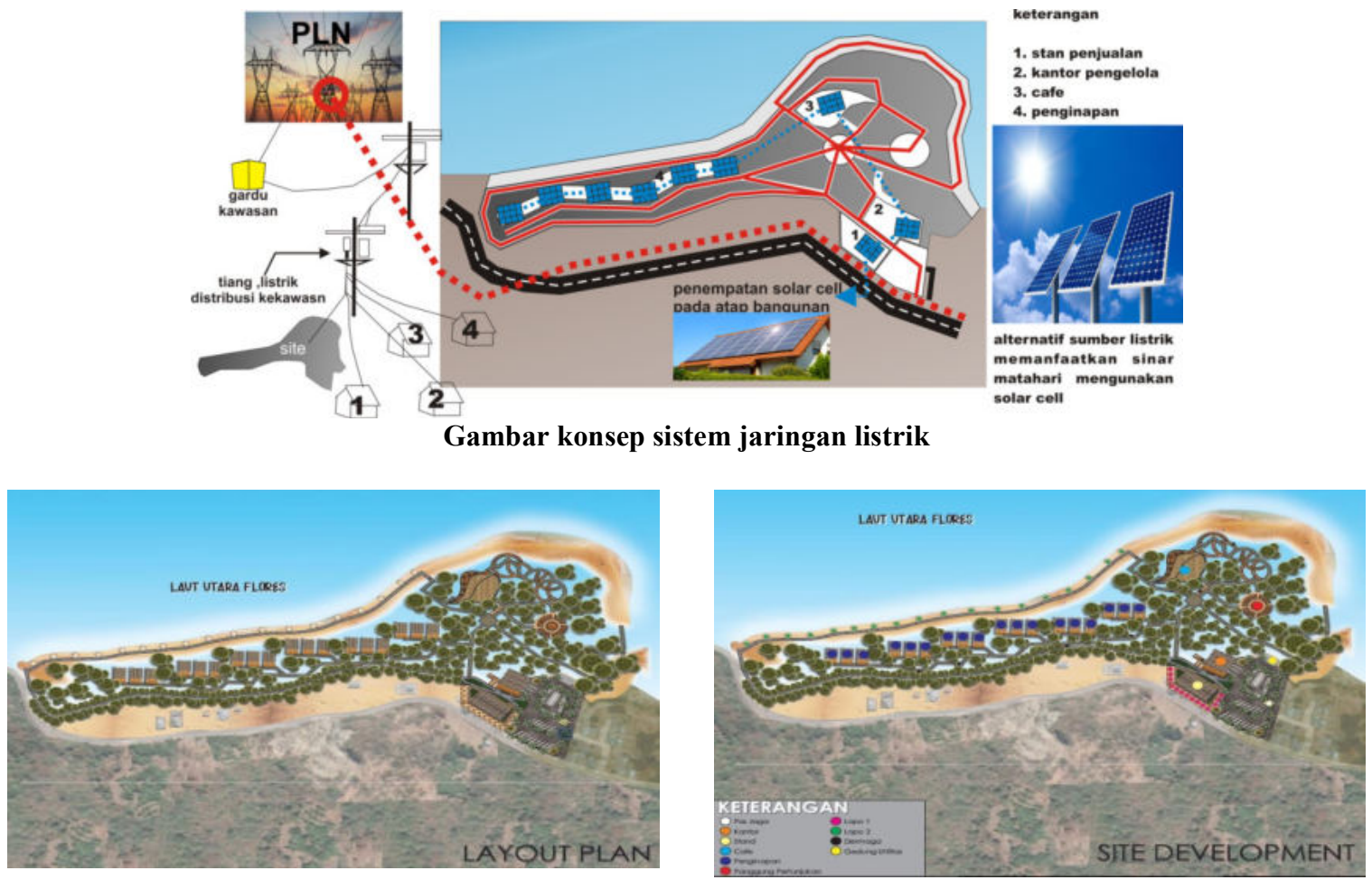

Gambar Hasil studi perancangan

\section{KESIMPULAN}

Hasil peracangan ini dapat disimpulkan sebagai berikut :

a. Desa Nira Nusa memiliki potensi wisata alam dengan beragam jenis seperti pantai dan hutan mangrove. Namun berbagai potensi wisata yang cukup beragam ini belum dikemas secara menarik. Sehingga secara optimal belum bisa mengangkat citra Desa Nira Nusa Sebagai tujuan berwisata.

b. Pengembangan Kawasan Hutan Mangrove Di Desa Nira Nusa Kecamatan Maurole Kabupaten Ende mengunakan penerapan tema ekowisata. Tema ekowisata digunakan untuk mewakili gambaran 
tentang tempat wisata yang berada pada kawasan pesisir yang dapat mengambarkan citra obyek sebagai tempat wisata yang memberikan tempat itu menjadi sebuah tempat ekowisata yang berbasis masyarakat. Sehingga masyarakat dapat mengolah dan menjaga kelestarian hutan mangrove tersebut dengan baik.

\section{DAFTAR PUSTAKA}

Alim Sumarno. (2012). Perbedaan Penelitian dan Pengembangan.

Anonim, 1990, Undang-Undang No. 9 Tahun 1999 Tentang Kepariwisataan, Jakarta.

Anonim, 2004. Peraturan Menteri Kehutanan No.03/MENHUT-V tentang Pedoman Pembuatan Tanaman Rehabilitasi Mangrove Gerakan Rehabilitasi Hutan dan Lahan

A, Yoeti, Oka. Edisi Revisi 1996, Pengantar Ilmu Pariwisata, Penerbit Angkasa, Bandung.

Departemen Kebudayaan Dan Pariwisata, 2009. Prinsip Dan Kriteria Ekowisata Berbasis Masyarakat, Kerjasama Direktorat Produk Pariwisata Direktorat Jenderal Pengembangan Destinasi Pariwisata Dan Wwf-Indonesia.

Direktorat Jenderal Kehutanan. 1978. Pedoman Silvikultur Hutan Payau. Surat Keputusan Direktorat Jenderal Kehutanan No. 60/kpts/DJ/I/1978. Jakarta: Direktorat Jenderal Kehutanan.

Fandeli, Chafid, Pengusaha Ekowisata, Yogyakarta : Pustaka Pelajar, 2000.

FAO. 1994. Mangrove forest management guidelines. FAO Forestry Paper No.117. Rome: FAO.

Hakim, L. 2004.Dasar-Dasar Ekowisata. Bayumedia Publishing. Jawa Timur.

Irawan, Koko. 2010. Potensi Obyek Wisata Sebagai Daya Tarik Wisata. Yogyakarta: Kertas Karya

James , Spillane, J. (1982:20). Pariwisata Indonesia, Sejarah dan Prospeknya.

Kementerian Dalam Negeri. (2009). Peraturan Menteri Dalam Negeri No.33 Tahun 2009 tentang Pedoman Pengembangan Ekowisata di Daerah. Jakarta: Kementerian Dalam Negeri.

Kitamura, S., Anwar, C., Chainago, A dan Baba S. 1997.Buku Panduan Mangrove di Indonesia Bali dan Lombok. Jaya Abadi. Denpasar.

Kodyat, H 1983. Sejarah Pariwisata dan Perkembangnannya di Indonesia.PT GramediaPustaka Utama. Jakarta.

Kustanti A, Yulia RF. 2005. Laporan Pengelolaan Terpadu hutan Mangrove kerjasama : masyarakat, Universitas lampung, dan Kabupaten Lampung Timur. Universitas Lampung. Bandar Lampung.

Massaut L. 1999. Mangrove Management and Shrimp Aquaculture Department of Fisheries and Allied aquaculture and International Center for Aquaculture and Aquatic Environments Auburn University. Alabama. 45 pp.

Tomlinson, P.B. 1986. The Botany of Mangroves. Cambridge University Press, Cambridge, U.K.

Richard Sihite dalam Marpaung dan Bahar. 2000: 46-47. Pariwisata.www.google.com diakses pada 28 maret 2019.

Rusila Noor, Y. 1999. Panduan pengenalan manggrove di Indonesia.PHKA / WI - IP, Bogor.

Sinaga, Supriono. 2010. "Potensi dan Pengembangan Objek Wisata Di Kabupaten

Tapanuli Tengah”. Kertas Karya. Program DIII Pariwisata. Universitas Sumatera Utara

Suyitno. (2001). Perencanaan Wisata. Yogyakarta: Kanisius.

Wiharyanto, D., 2007, "Kajian Pengembangan Ekowisata Mangrove di Kawasan Konservasi Pelabuhan Tengkayu II Kota Tarakan Kalimantan Timur", Tesis: Institut Pertanian Bogor.

https://www.tubancity.com/definisi-wisata-bahari.html

https://foresteract.com/taman-wisata-alam-angke-kapuk-taman-wisata-paling-asik/

https://ulinbareng.wordpress.com/2016/08/25/jenis-jenis-wisata

https://www.academia.edu/29883289/Menjelajah_Mangrove_Surabaya

https://docplayer.info/394191-Prinsip-dan-kriteria-ekowisata-berbasis masyarakat.html

http://etheses.uin-malang.ac.id/3103/1/11660034.pdf 